$p$-ISSN 1693-9484, $e$-ISSN : 2621-8313

Majalah Ilmiah Bahari Jogja (MIBJ)

Vol. 18 No. 1, Februari 2020 (57-70)

DOI : $10.33489 /$ mibj.v18i1.228

(C) 2020 Sekolah Tinggi Maritim Yogyakarta

\title{
Penukaran Delivery Order Online dan E-Container Equipment Interchange Receipt Terhadap Impor Barang Menggunakan Petikemas
}

\author{
Juli Prastyorini ${ }^{1 *}$, Fahreza Achmad Syaputra ${ }^{1}$ \\ ${ }^{1}$ STIA dan Manajemen Kepelabuhanan (STIAMAK) Barunawati Surabaya, Jl. Perak \\ Barat No. 173 Surabaya, Indonesia \\ * Corresponding Author. Email: juli.prastyorini@ stiamak.ac.id. Telp :082237473884
}

\begin{abstract}
Abstrak
Penelitian ini bertujuan untuk mendeskripsikan tentang penanganan barang impor menggunakan petikemas dengan menggunakan delivery order online dan elektronik container equipment interchange receipt. Dalam penelitian metode yang digunakan ini ialah metode deskriptif. Sumber data yang digunakan dalam penelitian ini adalah wawancara dan pengamatan langsung di lapangan. Hasil penelitian ini memperlihatkan proses penanganan impor barang menggunakan bill of lading original yang ditukar dengan delivery order online yang masih menggunakan sistem manual di perusahaan pelayaran dan di job order-kan menjadi elektronik container equipment interchange receipt menggunakan aplikasi clique-247 untuk petikemas keluar dari pelabuhan sandar guna mempercepat penanganan impor barang menggunakan petikemas bagi pengguna jasa dan pemberi pelayanan jasa untuk bekerja dengan praktis dan cepat. Berdasarkan hasil wawancara, pengamatan, studi dokumentasi dan studi pustaka dalam penelitian, dapat diperoleh kesimpulan bahwa delivery order online dan elektronik container equipment interchange receipt yang dikerjakan oleh operasional Ekspedisi Muatan kapal Laut dapat mengeluarkan petikemas dalam pelabuhan sandar kapal. Artinya, model konseptual yang dikembangkan dan dilandasi oleh teori hampir sepenuhnya didukung oleh fakta yang ada dilapangan.
\end{abstract}

Kata kunci : Delivery Order Online dan e-Container Equipment Interchange Receipt

\begin{abstract}
This study aims to describe the handling of imported goods using containers using online delivery orders and electronic container interchange receipt equipment. In research the method used is descriptive method. Data sources used in this study were interviews and direct observations in the field. The results of this study show the process of handling imported goods using original bill of lading exchanged with online delivery orders that still use manual systems at shipping companies and in job orders into electronic container equipment interchange receipts using the application clique-247 for containers out of the port of sandar in order to speed up handling of imported goods using containers for service users and service providers to work practically and quickly. Based on the results of interviews, observations, documentation studies and literature studies in research, it can be concluded that online and electronic delivery orders - container equipment interchange receipts that are carried out by the Sea Cargo Expedition operations can issue containers in the port of ship berth. That is, the
\end{abstract}


conceptual model developed and based on theory is almost completely supported by the facts in the field.

Keywords : Delivery Order Online and e-Container Equipment Interchange Receipt

\section{PENDAHULUAN}

Pada mulanya hubungan perdagangan hanya terbatas pada satu wilayah negara yang tertentu, tetapi dengan semakin berkembangnya arus perdagangan maka hubungan dagang tersebut tidak hanya dilakukan antara para pengusaha dalam satu wilayah negara saja, tetapi juga dengan para pedagang dari negara lain, tidak terkecuali Indonesia. Bahkan hubungan-hubungan dagang tersebut semakin beraneka ragam, termasuk cara pembayarannya. Kegiatan ekspor impor didasari oleh kondisi bahwa tidak ada suatu negara yang benar-benar mandiri karena satu sama lain saling membutuhkan dan saling mengisi.

Pelindo 1 (satu) pertama kali berupaya meningkatkan kualitas pelayanannya, khususnya dengan menggunakan teknologi informasi untuk semakin mempermudah pengguna jasanya. Hal ini dibuktikan dengan Go-Live aplikasi Inapornet dan Delivery Order online. Dalam acara yang digelar Kementrian Perhubungan di Jakarta ini, Aplikasi Inapornet barang versi 2.0 dan layanan Delivery Order (DO) Online untuk empat pelabuhan utama, yaitu : Pelabuhan Belawan, Pelabuhan Tanjung Priok, Pelabuhan Tanjung Perak dan Makassar serta 1 (satu) pelabuhan kelas 1 yaitu Pelabuhan Tanjung emas, Semarang resmi diluncurkan.

Pada kesempatan tersebut, Menteri Perhubungan Budi Karya Sumadi secara resmi meluncurkan (Go-Live) aplikasi Inaportnet barang versi 2.0 dan Delivery Order Online bertempat di Mandarin Oriental Hotel Jakarta yang dihadiri oleh Deputi Bidang Koordinasi Percepatan Infrastuktur dan Pengembangan Wilayah Kemenko Bidang Maritim, Dirjen Bea dan Cukai Kementrian Keuangan, Dirjen Perhubungan Laut Kementrian Perhubungan, serta para Stakeholder di bidang kepelabuhanan.

Direktur Jendral Perhubungan Laut, R Agus H. Purnomo menambahkan bahwa dengan penerapan Inapornet 2.0, maka pelayanan di pelabuhan menjadi lebih cepat, seperti mempercepat proses lapor kedatangan dan keberangkatan kapal dari 1 (satu) hari menjadi 10 menit, kemudian dalam pengurusan hanya membutuhkan akses internet dan tidak perlu mengeluarkan biaya untuk operasional pengurusan pelayanan kapal keotoritas Pelabuhan Syahbandar dan Terminal, serta menjadikan pelayanan yang transparan dengan informasi kapal dan barang yang dapat dipantau dengan Inaportnet 2.0.

Inaportnet adalah portal elektronik yang terbuka dan netral guna memfasilitasi pertukaran data dan informasi layanan kepelabuhan secar cepat, aman, netral dan mudah terigntegrasi dengan instansi pemerintah terkait, badan usaha pelabuhan dan pelaku industri logistik untuk meningkatkan daya saing komunitas logistik Indonesia. Elektronik Delivery Order adalah salah satu produk yang dikeluarkan oleh PT. SENT (Solusi Emas Nusantara Teknologi) untuk 
mendukung pelaksanaan pengiriman barang secara elektronik (delivery order online) untuk barang impor di pelabuhan baik itu request DO (Delivery Order), pembayaran $D O$ (Delivery order) secara non tunai maupun pengiriman $D O$ (Delivery order) secara elektronik yang bertujuan untuk meningkatkan kelancaran arus barang dan penurunan biaya logistik di pelabuhan. Selain itu dengan menggunakan e-DO (electronic-Delivery Order) tentuya dapat memudahkan para pengguna jasa tanpa harus dating ke kantor atau loket shiiping lines.

Selama ini prosedur kepabeanan dianggap sangat rumit dan berbelit-belit. Namun berbagai cara telah dilakukan untuk memperlancar prosedur arus dokumen dan barang maupun petikemas dengan berbagai peraturan dan pengendalian peralatan monitor secara elektronik. Hal ini telah dilakukan oleh Bea dan Cukai mauoun port authoritydari pelabuhan diberbagai Negara termasuk di Indonesia. Petikemas merupakan sarana terpenting untuk total transport, dimana hambatan yang didapat disuatu negara dapat mempengaruhi arus barang dan petikemas di negara lain.

Di jaman yang serba digital ini, perkembangan teknologi semakin cepat dan memudahkan para pengguna jasa mengerjakan pekerjaannya. Sistem elektronik, merupakan ide yang tepat untuk dilaksanakannya kegiatan impor barang. Proses delivery order membuat pekerjaan cepat dan tidak menunggu lama di kantor pelayaran dan elektronik container equipment interchange receipt, dimunculkannya aplikasi yang bernama clique247 di Terminal Petikemas Surabaya, tidak antri seperti yang dahulu pada saat menumpuk dokumen dan menunggunya berjam - jam lamanya. Hal ini dirasakan langsung ditempat saya melakukan suatu penelitian yaitu di kantor Ekspedisi Muatan Kapal Laut (EMKL) PT. Tirta Nusantara. Oleh sebab itu, kami mengambil penelitian dengan judul "Analisis Penukaran Delivery Order Online dan Elektronik Container Equipment Interchange Receipt Terhadap Impor Barang Menggunakan Petikemas.

\section{KAJIAN LITERATUR}

\section{Delivery Order}

Menurut M. Iqbal Yahya dalam bukunya yang berjudul suatu pengantar Ekspor Impor (2012) delivery order disebut juga sebagai surat perintah penyerahan barang. Meskipun penggunaannya sangat luas dalam konteks perintah penyerahan barang, akan tetapi dalam pembahasan ini, delivery order $(D O)$ yang diperoleh dari pertukaran original bill of lading $(B / l)$ kepada maskapai pelayaran. Selanjutnya delivery order tersebut yang akan dibawa importer ke pelabuhan bongkar dan digunakan sebagai bukti untuk pengambilan barang di gudang maskapai.

Delivery Order $(D O)$ adalah surat yang menyatakan kepemilikan atas barang atau muatan. Delivery order dapat diperoleh dengan menukarkan bill of lading ke perusahaan pelayaran. Delivery order digunakan untuk mengeluarkan container full ke luar dari wilayah otoritas pelabuhan. Delivery order dapat diperoleh setelah mengirimkan shipping instruction $(S I)$ kepada pihak pelayaran, setelah itu barulah perusahaan pelayaran menerbitkan Delivery order. 
Dapat disimpulkan Delivery Order adalah surat yang diterbitkan pihak shipping (pelayaran) atau forwader kepada shipper (pemilik barang) sebagai tanda bukti pengambilan container kosong atau tanda bukti pengiriman barang dari gudang shipper ke gudang. (warehouse).

\section{Delivery Order Online}

Peraturan Menteri Perhubungan Republik Indonesia nomor PM 120 Tahun 2017 tentang pelayanan pengiriman pesanan secara elektronik (Delivery Order Online) untuk barang impor pelabuhan. Bahwa untuk meningkatkan kelancaran percepatan pelayanan pengeluaran barang dari pelabuhan melalui pelaksanaan pesanan secara elektronik (delivery Order Online) untuk barang impor.

Pengiriman pesanan secara elektronik (delivery order online) yang selanjutnya disebut $D O$ Online adalah surat bukti penyerahan barang yang dikeluarkan perusahaan angkutan laut (perusahaan pelayaran) atau kuasanya kepada pemilik barang yang merupakan suatu bukti pengiriman barang.

\section{Elektronik}

Elektronik adalah alat yang dibuat berdasarkan prinsip elektronika serta hal atau benda yang menggunakan alat-alat yang dibentuk atau bekerja atas dasar elektronika. Informasi elektronik adalah satu atau sekumpulan data elektronik, termasuk tetapi tidak terbatas pada tulisan, suara, gambar, peta, rancangan, foto, elektronik data interchange (ED4, surat elektronik (electronic mail), telegram, teleks, telecopy atau sejenisnya, huruf, tanda, angka, kode akses, simbol atau perforasi yang telah diolah yang memiliki arti atau dapat dipahami oleh orang yang memahaminya. Transaksi elektronik adalah perbuatan hukum yang dilakukan dengan menggunakan komputer, jaringan computer dan atau media elektronik lainnya.

Sistem elektronik adalah serangkaian perangkat dan prosedur elektronik yang berfungsi mempersiapkan, mengumpulkan, mengolah, menganalisis, menyimpan, menampilkan, mengumumkan, mengirimkan dan menyebarkan informasi elektronik. Dokumen elektronik adalah setiap informasi elektronik yang dibuat, diteruskan, dikirimkan, diterima, disimpan dalam bentuk analog, digital, elektromagnetik, optikal atau sejenisnya yang dapat dilihat, ditampilkan, dan/atau didengar, melalui komputer atau sistem elektronik, termasuk tetapi tidak terbatas pada tulisan, suara, gambar, peta, rancangan, foto atau sejenisnya, huruf, tanda, angka, kode akses, simbol, atau perforasi yang memiliki makna atau arti atau dapat dipahami orang yang mampu memahaminya.

Data elektronik (electronic data) adalah informasi atau rangkaian informasi yang disusun atau dihimpun, diolah, dan dikirimkan dengan menggunakan perangkat computer sebagai alat pemroses dan transfer data elektronik. Pertukaran data elektronik (electronic data interchange) adalah sistem transfer data berbasis computer yang dapat mengirimkan dokumen terstruktur yang berstandart internasional dan telah secara luas dipraktikan oleh negara anggota World Custom Organization (WCO).

Penggunaan dokumen elektronik disempurnakan dengan Undang-Undang no. 17 Tahun 2006, pasal 5A meyatakan demikian :

a. Pemberitahuan pabean sebagaimana dimaksud dalam pasal 5 (lima) ayat 
b. Dapat disampaikan dalam bentuk tulisan diatas formulir atau dalam bentuk data elektronik

c. Data elektronik sebagaimana yang dimaksud dengan ayat (1) satu merupakan alat bukti yang sah menurut undang-undang ini.

\section{Container Equipment Interchange Receipt (CEIR)}

PT. Terminal Petikemas Surabaya (TPS) Tanjung Perak, Surabaya, Jawa Timur berencana menggunakan layanan dalam jaringan (daring/online) untuk servis dokumen " Container and Equipment Interchange Receipt (CEIR) di wilayah itu. Direktur utama PT. Terminal Petikemas Surabaya, Rabu (6/9/2017) mengatakan Container Equipment Interchange Receipt (CEIR) adalah dokumen syarat mengeluarkan petikemas yang telah dinyatakan selesai oleh instansi terkait.

Beberapa pelanggan bahwa saat ini TPS berusaha berinovasi kedepannya EMKL mencetak CEIR secara online, sopir truk yang akan mengabil dan mengirim petikemas hanya menunjukan surat elektronik yang berisi barcode sebagai verifikasi agar dapat mengambil atau mengirim petikemas yang ada di TPS.

\section{METODE PENELITIAN}

\section{Jenis Penelitian}

Pendekatan dalam penelitian ini adalah penelitian kualitatif. Metode yang digunakan adalah studi kasus. Menurut (Sutopo,2002) dengan memperhatikan beberapa batasan penelitian kualitatif, dapat dipahami bahwa pada hakikatnya penelitian kualitatif itu merupakan studi kasus, yaitu penelitian yang terikat pada konteksnya. (Farida Nugrahani, 2014).

Menurut (Yin,2000) dalam melakukan penelitian studi kasus, peneliti dapat berinteraksi secara terus-menerus dengan isu-isu teoritis yang dikaji dan dengan data-data yang dikumpulkan. Selain itu, juga dapat menggunakan berbagai bukti penelitian tentang peristiwa yang berkonteks kehidupan nyata. Peneliti memilih pendekatan ini karena judul yang diangkat peneliti merupakan sebuah peristiwa dalam kehidupan yang nyata. (Farida Nugrahani, 2014).

\section{Subjek Penelitian}

Menurut (Spradley,1979) subjek penelitian adalah sumber informasi dalam penelitian, sementara itu menurut (Moleong,1990) subjek penelitian adalah orang dalam pada latar penelitian, yaitu orang yang dimanfaatkan untuk memberi informasi tentang situasi dan kondisi latar penelitian. (Farida Nugrahani, 2014).

Berbagai sumber oleh peneliti dalam memilih subjek penelitian, yaitu:

a. Pihak external, yaitu :

1) Perusahaan pelayaran

2) Customer service PT. Terminal Petikemas Surabaya

3) Perusahaan Depo petikemas

b. Pihak Internal, yaitu :

Bagian dinas luar PT. Tirta Nusantara 


\section{Prosedur Penelitian}

Setiap kegiatan penelitian selalu mengikuti suatu proses yang bertahap. Neuman (2000) "menulis bahwa penelitian kualitatif dimulai dengan penelitian topik". Topik dalam penelitian kualitatif biasanya agak umum. Topik ini kemudian berkembang mengerucut menjadi lebih spesifik. Sesudah topiknya mengerucut, maka dilanjutkan dengan memeriksa topic tersebut pada buku-buku atau jurnal ilmiah yang dikenal dengan penelusuran literature atau kepustakaan. Hasil bacaan dari buku dan jurnal ilmiah akan memberikan gambaranyang jelas bagaimana topik itu dibahas dan dimengerti oleh para penulis atau peneliti sebelumnya. Bagian ini sering disebut dengan literature review setelah penelusuran kepustakaan, dilanjutkan dengan pengumpulan data, analisis data, penafsiran dan pelaporan.

\section{Instrumen Penelitian}

Instrument penelitian kualitatif tidaklah eksternal (objektif) tetapi internal (subjektif). Instrument bukanlah suatu definisi operasional atau berupa alat lainnya, melainkan manusianya (peneliti), yang merupakan perabot terlatih, sensitif dan lentur, sehingga mampu menjaringelemen-elemen yang menonjol dan mentargetkan kelengkapan penelitian. Peneliti yang berpengalaman akan menjadi instrument yang lebih sempurna, jika bersikap lentur dan terbuka, teliti dan peka, serta mampu memahami proses pelaksanaan penelitian. Peneliti yang demikian itu akan menjadi instrument yang dapat menjamin kelengkapan penelitian, dan kedalaman data yang diperoleh, serta kemantapan dalam menentukan hasil penelitian. Sementara itu, dalam desain penelitian kuantitatif (konvensional), spesifikasi instrument sangat penting, bukan hanya karena instrument merupakan alat pengumpul data, tetapi karena secara simultan instrumen merupakan definisi operasional mengenai variabel yang terlibat. Instrumen juga penting untuk memperoleh validitas dan realibilitas yang tinggi, dan tidak terpengaruh secara ekternal oleh manusia.

Dalam penelitian kualitatif, yang menjadi instrument atau alat penelitian adalah peneliti itu sendiri sehingga peneliti harus "divalidasi". Validasi terhadap peneliti, meliputi : pemahaman, metode penelitian kualitatif, penguasaan wawasan terhadap bidang yang diteliti, kesiapan peneliti untuk memasuki objek penelitian baik secara akademik dan logikanya (Sugiyono,2009).

\section{Jenis dan Sumber Data}

Dalam penelitian ini, jenis dan sumber data yang diperoleh dari informan, informanya ialah :

a. Perusahaan pelayaran

1) Kasir PT. Evergreen Indonesia

2) Document Service PT. APL Securities S.A.R.L

3) Kasir PT. Tresnamuda Sejati

b. Customer service PT. Terminal Petikemas Surabaya

Customer Service PT. Terminal Petikemas Surabaya

c. Perusahaan Depo petikemas

Operasional Inventory Control

d. Karyawan PT. Tirta Nusantara 
Dinas Luar PT. Tirta Nusantara

\section{Metode Pengumpulan Data}

Berdasarkan berbagai jenis data yang dibutuhkan dan didapatkan penggalian informasi di lapangan, teknik pengumpulan data sebagai berikut:

a. Observasi

Observasi merupakan bagian yang sangat penting dalam penelitian kualitatif. Melalui peneliti dapat mendokumentasikan dan merefleksi secara sistematis terhadap kegiatan dan interaksi subjek penelitian. Observasi ini tahapannya meliputi, pengamatan secara umum mengenai hal-hal yamg sekiranya berkaitan masalah yang diteliti. Setelah itu, identifikasi aspek-aspek yang menjadi pusat perhatian, pembatasan objek dan pencatatan. Peneliti melakukan observasi terhadap penanganan penukaran $D O$ di pelayaran. Pihak pelayaran memajang pemberitahuan memo syarat dan ketentuan untuk penukaran $D O$ dan peneliti menyatat di buku atau memfotonya untuk disimpan di handphone, supaya tidak lupa kalau ada penukaran $D O$ di pelayaran tersebut lagi, apa saja persyaratannya.

b. Wawancara

Wawancara adalah merupakan pertemuan dua orang untuk bertukar informasi dan ide melalui tanya jawab, sehingga dapat dikonstruksikan makna dalam satu topik tertentu. Tehnik pengumpulan data dengan wawancara digunakan sebagai tehnik pengumpulan data apabila peneliti ingin melakukan studi pendahuluan untuk menemukan permasalahan yang harus diteliti, dan juga apabila peneliti ingin mengetahui hal-hal dari responden yang lebih mendalam dan jumlah repondennya sedikit/kecil.

Metode wawancara yang digunakan dalam penelitian ini adalah wawancara tidak terstruktur (unstructured interview), wawancara ini adalah wawancara yang bebas dimana peneliti tidak menggunakan pedoman wawancara yang telah tersusun secara sistematis dan lengkap untuk pengumpulan datanya. Peneliti melakukan wawancara dengan pihak-pihak yang berkaitan dengan yang peneliti teliti. Peneliti melakukan Tanya jawab dan seorang narasumber menjawabnya lalu peneliti mencatat apa yang dijawab oleh narasumber tersebut.

c. Studi Dokumentasi

Dokumentasi sediri bisa diartikan catatan peristiwa yang sudah berlalu. Dokumen ini bisa berupa, tulisan, gambar, catatan harian, biografi, peraturan, kebijakan, dan lain-lain. Studi dokumenter (documentary study) merupakan suatu teknik pengumpulan data dengan menghimpun dan menganalisis dokumen-dokumen, baik dokumen tertulis, gambar maupun elektronik. Dokumen yang dihimpun dipilih yang sesuai dengan tujuan dan fokus masalah. Tehnik pengumpulan data dengan dokumentasi ini digunakan sebagai pelengkap antara wawancara dan observasi supaya data lebih kredibel. Catatan tulisan terdahulu, bila ada yang masih digunakan persyaratannya oleh perusahaan tersebut, maka catatan tersebut masih penting dan bisa digunakan kembali. Foto-foto yang disimpan di handphone dinas luar mengenai penukaran $D O$ bisa digunakan kembali bila persyaratan tersebut masih digunakan perusahaan sampai sekarang. 
d. Studi Pustaka

Menurut M.Nazir (1988) dalam bukunya yang berjudul 'Metode Penelitian' mengemukakan bahwa yang dimaksud dengan: "Studi kepustakaan adalah langkah yang penting dimana setelah seorang peneliti menetapkan topik penelitia, langlah selanjutnya adalah melakukan kajian yang berkaitan dengan teori yang berkaitan dengan topic penelitian. teknik pengumpulan data dengan mengadakan studi penelaahan terhadap buku-buku, litertur-literatur, catatancatatan, dan laporan-laporan yang ada hubungannya dengan masalah yang dipecahkan." (Nazir,1988).

Studi Kepustakaan yaitu mengadakan penelitian dengan cara mempelajari dan membaca literatur-literatur yang ada hubungannya dengan permasalahan yang menjadi obyek penelitian. Peneliti memilih kajian/literature bersumber dari buku yang dipinjam diperpustakaan. Diambil yang penting dan sesuai dari judul yang peneliti kerjakan.

\section{Analisa Data}

Dalam penelitian kualitatif terdapat banyak model rancangan. Penggunaan salah model rancangan itu disesuaikan dengan fokus penelitian. Setiap model rancangan analisis data datanya berbeda. Proses analisisi data dalam penelitian kualitatif dimulai dengan menelaah seluruh data yang tersedia dari berbagai sumber. Data yang beraneka ragam itu dibaca dengan cermat, dipelajari dan direduksi dengan jalan membuat rangkuman inti (abstraksi). Setelah menuliskan abstraksi, data disusun sesuai tema-temanya, kemudian dilakukan penafsiran untuk memperoleh temuan sementara, yang secara berulang-ulang perlu direduksi agar mampu menjadi teori substantif. Analisis data kualitatif merupakan sebuah proses yang terdiri atas langkah-langkah berikut.

a. Mencatat peristiwa yang ada di lapangan dalam catatan lapangan, kemudian diberi kode sehingga sumber data dapat ditelusuri.

b. Mengumpulkan, memilah-milah, melakukan klasifikasi, mensintesiskan, membuat ikhtisar, dan member indeks.

c. Berpikir untuk memperjelas kategori data sehingga data yang ada bermakna dengan mencari dan menemukan pola serta hubungan-hubungan dan membuat temuan - temuan umum.

Analisis data model interaktif, dikemukakan oleh Miles \& Huberman (1984). Analisis data model interaktif ini memiliki tiga komponen, yaitu reduksi data, sajian data dan penarikan kesimpulan/verifikasi. Menurut Miles \& Huberman (1984) ketiga komponen utama yang terdapat dalam analisis data kualitatif, sebab hubungan dan keterkaitan anatara ketiga komponen itu perlu dikomparasikan untuk menentukan arahan isi simpulan sebagai hasil penelitian.

\section{Keabsahan Data}

Dalam Penelitian kualitatif faktor keabsahan data juga sangat diperhatikan karena suatu hasil penelitian tidak ada artinya jika tidak mendapat pengakuan atau terpecaya. Untuk memperoleh pengakuan terhadap hasil penelitian ini terletak pada keabsahan data penelitian yang telah dikumpulkan. Berpedoman kepada pendapat Lincoln \& Guba (1985), untuk mencapai kebenaran dipergunakan teknik 
kredibilitas, transferabilitas, dependabilitas, dan konfirmabilitas yang terkait dengan proses pengumpulan dan analisis data.

\section{HASIL DAN PEMBAHASAN}

Hasil penelitian ini diperoleh dengan teknik wawancara dan pengamatan dengan narasumber pihak perusahaan PT. Tirta Nusantara sebagai kunci berjalannya pekerjaan untuk penukaran delivery order online dan e-container equipment interchange receipt. Dimana diarahkan untuk mengetahui bagaimana prosedurnya, pemberitahuan kedatangan kapal dilihat melalui web perusahaan pelabuhan sandar, penukaran Delivery order di pelayaran dan pencetakan elektronik. Container Equipment Interchange Receipt (e-CEIR) di pelabuhan sandar atau bisa langsung dicetak di kantor perusahaan menggunakan aplikasi clique-247. Setelah itu dibimbing rekan dinas luar untuk mengetahui lebih rinci lagi prosedur pengerjaannya dengan membaca catatan-catatn terdahulu, apakah ada hal yang berbeda dan hal yang sama dalam melakukan penukaran delivery order dan elektronik. Container Equipment Interchange Receipt (e-CEIR).

\section{Analisis Penukaran Delivery Order Online}

Pengiriman pesanan secara elektronik (Delivery Order online) yang selanjutnya disebut $D O$ Online adalah surat bukti penyerahan barang yang dikeluarkan perusahaan angkutan laut (perusahaan pelayaran) atau kuasanya kepada pemilik barang yang merupakan suatu bukti pengiriman barang. Adapun penukaran Delivery Order secara online yang dilakukan dengan tanya jawab dan pengamatan langsung dilapangan, yaitu :

a. Memeriksa sandar kapal di web access pelabuhan sandar kapal

b. Membawa kelengkapan dokumen, yaitu :

1) Bill Of Lading ( $B / L)$

2) Surat Persetujuan Pinjam Container

3) Surat kuasa pengambilan Delivery Oreder dari importir dan disertai email.

4) Permohonan interchange

5) Foto kopi identitas diri

c. Men-transfer uang ke rekening pelayaran atau membayarnya dengan uang tunai di kasir, tergantung kebijakan pelayaran.

d. Menumpuk dokumen kebagian pelayanan dokumen impor.

e. Delivery order akan dikirim ke email perusahaan Ekspedisi Muatan Kapal Laut (EMKL) atau diberikan langsung dan mendapatkan nomer Delivery Order dan pin Delivery Order

\section{Analisis Pencetakan $\boldsymbol{e}$-CEIR di Terminal Petikemas Surabaya}

Data elektronik adalah informasi atau rangkaian informasi yang disusun atau dihimpun, diolah, dan dikirimkan dengan menggunakan perangkat computer sebagai alat pemroses dan transfer data elektronik. Container Equipment Interchange Receipt (CEIR) adalah tanda terima pergerakan arah petikemas yang telah disetujui oleh export superintendent (superitenden ekspor).Adapun 
Pencetakan elektronik - Container Equipment Interchange Receipt (e-CEIR) berfungsi untuk dokumen yang digunakan untuk mengeluarkan petikemas dari pelabuhan sandar kapal. Jadi Pengaplikasian pencetakan elektronik - Container Equipment Interchange Receipt (e-CEIR)melalui aplikasi clique-247 di Terminal Petikemas Surabaya adalah sebagai berikut :

a. Ketik clique - 247

b. Klik clique -247

c. Masukan email dan password perusahaan

d. Lalu tekan new booking pada pojok kanan atas dalam aplikasi clique-247

e. Pilih service type - import delivery

f. BC pilih - SPPB (Surat persetujuan pengeluaran barang)

g. Cleareance number - diisi dengan tulisan nomor dibawah tulisan besar SPPB (Surat Persetujuan Pengeluaran Barang), tanggal disebalahnya tidak usah ditambahi

h. Select cleareance document date - diisi dengan tanggal keluarnya SPPB (Surat Persetujuan Pengeluaran Barang)

i. Select plan date - diisi tanggal berapa keluarnya petikemas di pelabuhan

j. Departure carrier - truck

k. Tekan submit

1. Lalu keluar berapa petikemas yang akan dikeluarkan dan estimasi harga

m. Muncul nama perusahaan dan bank yang dipakai oleh perusahaan

n. Centang kotak dibawah akun bank perusahaan

o. Jika benar klik continue

p. Lalu otomatis diauto debit oleh TPS

q. Kembali ke menu halaman utama

r. Tunggu sampai disetujui oleh TPS

s. Bila di kotak booking berwarna hijau maka pilih container satu per satu yang akan dikeluarkan

t. Lalu diprint sebanyak 3 rangkap

\section{Temuan Hasil Penelitian}

Dalam penelitian kualitatif temuan hasil penelitian merupakan tahap yang bermanfaat untuk menelaah data yang telah diperoleh dari beberapa pengamatan dan diperoleh dari informan yang telah dilakukan selama penelitian berlangsung. Selain itu juga berguna untuk menjelaskan dan memastikan kebenaran temuan penelitian. Temuan-temuan penelitian ini dilakukan sejak awal dam bersamaan dengan proses pengumpulan data di lapangan.

Adapun dari penelitian yang telah dilakukan peneliti mendapatkan beberapa temuan yang dapat menggambarkan proses penukaran delivery order dan pencetakan elektronik-container equipment interchange receipt yang terlihat dari hasil wawancara dan pengamatan dimana proses penukaran delivery order dan pencetakan elektronik-container equipment interchange receipt terjadi didalam proses impor barang menggunakan petikemas. 
Tabel 1. Perbandingan Penukaran Delivery Order

\begin{tabular}{cccc}
\hline $\begin{array}{c}\text { Sistem } \\
\text { Penukaran }\end{array}$ & $\begin{array}{c}\text { Perusahaan } \\
\text { Pelayaran }\end{array}$ & Antrian & $\begin{array}{c}\text { Waktu Penyelesaian dan } \\
\text { Perjalanan ke Kantor }\end{array}$ \\
\hline Manual & Evergreen & 1 antrian & 45 menit \\
Kirim & PT. Container & 1 antrian & 20 menit \\
Email/Sistem & Maritim Activities & & \\
Elektronik & CMA-CGM & & \\
\hline
\end{tabular}

\section{Research Gap}

Dalam proses penukaran delivery order dan pencetakan elektronikcontainer equipment interchange receipt (e-CEIR) di jaman yang sudah online, masih terdapat masalah-masalahatau hambatan-hambatan dalam pengerjaannya. Temuan-temuan masalah ini sangat penting dalam sebuah penelitian. Bila di jaman yang serba online dan elektronik dipandang secara praktis, tetapi terdapat sedikit kekurangan-kekurangan yang terjadi disetiap pengerjaannya. Dapat diketahui dalam pengamatan dan wawancara penelitian penukaran delivery order (DO) dan pencetakan elektronik-container equipment interchange receipt (eCEIR), terdapat penemuan masalah-masalah/gap tersebut adalah sebagai berikut:

a. Dengan melakukan wawancara dan pengamatan langsung dengan rekan dinas luar dalam sebuah penelitian, Penukaran bill of lading (B/L) dan dokumen lainnya dengan delivery order yang masih menggunakan sistem tumpuk dokumen/manual, memakan waktu di pelayaran. Pelayaran PT. Container Maritime Activities (CMA CGM, CNC dan ANL) sudah memulai dulu memberlakukan E-Receipt. Sebagai persiapan untuk pembaruan migrasi sistem serta proses elektronik dokumen lainnya elektronik-Delivery Order ( $E$-DO dan E-Payment) yang akan dilakukan pada awal juni 2018.

b. Pada tanggal 2 Juli 2019, mengamati langsung dan menukarkan Delivery Order di pelayaran PT. APL Securities S.A.R.L (APL), Terdapat penukaran delivery order yang tidak sesuai dari waktu sandar kapal. Estimasi kapal sandar tanggal 20 Juni 2019 dan dip roses tanggal 02 Juli 2019. Kebijakan perusahaan pelayaran yang tidak diketahui seorang dinas luar dan belum mendapatkan sosialisasi sebelumnya, terkena sanksi administratif bayar, dikarenakan terlambat menukarkan Delivery Order dari tanggal waktu perusahaan pelayaran PT. APL Securities S.A.R.L (Pelayaran APL). Batas penukaran Delivery Order dibayar paling lambat 7 (tujuh) hari dari kapal sandar

\section{Sebab Masalah}

Adapula sebab akibat masalah dalam penelitian di lapangan. Hal ini tidak jauh dari penemuan masalah sehari-hari yang ditekuni dalam penukaran delivery order dan pencetakan elektronik-container equipment interchange receipt. Maka dari itu, sebab akibat masalahnya adalah:

a. Penukaran delivery order yang menggunakan sistem tumpuk, akan memperlambat dan membuang waktu di pelayaran. Pada saat di lapangan 
menukarkan $D O$ di pelayaran APL pada tanggal 2 Juli 2019, terlihat jelas pelayaran PT. Container Maritim Activities (CMA CM, CNC dan ANL) tidak ada antrian sama sekali. Hal ini perlu di ikuti pelayaran-pelayaran lain sebagai gerakan inovasi sebuah percepatan dan penyederhanaan kerja dalam mengurus impor barang yang akan masuk di Indonesia.

b. Sebab tidak adanya pemberitahuan melalui sosialisasi/pengarahan kepada ekspedisi muatan kapal laut (EMKL) atau pemberitahuan di dinding pelayaran. EMKL tidak mengetahui adanya sanksi administrasi bila terlambat bayar penukaran delivery order. Hal ini sangat merugikan importir.

\section{Akibat Masalah}

a. Akibat dari itu pekerjaan penukakaran delivery order dengan sistem tumpuk kita harus ke pelayaran terlebih dahulu dan transfer pembayaran penukaran delivery order ke bank yang dituju perusahaan pelayaran. Hal ini memerlukan waktu yang lama untuk prosesnya penukaran delivery order. Hal yng paling ditakuti adalah antrian bank yang sangat memakan waktu.

b. Akibat dari itu dinas luar membayar menalangi dana lain untuk membayar biayanya dan kembali ke bank untuk transfer, belum lagi di bank sangat antri. Sangat merugikan waktu seorang dinas luar. Apalagi tambahan biaya seperti ini seorang pimpinan melalui bawahannya akan konfirmasi dulu ke pihak importir untuk mengetahu biaya tambahannya.

\section{Solusi Pemecahan Masalah}

a. Kementerian Perhubungan secara resmi meluncurkan (Go Live) Aplikasi Inaportnet Barang versi 2.0 dan layanan Delivery Order (DO) Online untuk 4 (empat) Pelabuhan Utama yaitu, Pelabuhan Belawan, Tanjung Priok, Tanjung Perak dan Makassar serta 1 (satu) Pelabuhan Kelas I yaitu Pelabuhan Tanjung Emas, Semarang. Terkait aplikasi Delivery Order Online, sesuai dengan amanat PM 120 tahun 2017 tentang Pelayanan Pengiriman Pesanan Secara Elektronik (Delivery Order Online), untuk barang impor di pelabuhan, pada pasal 8 (delapan) Peraturan Menteri tersebut menyatakan peraturan tersebut berlaku setelah 6 (enam) bulan terhitung sejak tanggal diundangkan yang artinya jatuh pada bulan Juni 2018. Untuk itu Delivery Order Online mulai diberlakukan di 4 (Empat) Pelabuhan Utama dan 1 (satu) pelabuhan kelas I yang termonitor di Inaportnet 2.0. Penerapan Delivery Order Online ini merupakan upaya mempercepat proses permintaan (request) Delivery Order, pembayaran DO, sampai penerbitan (release) Delivery Order oleh perusahaan pelayaran dengan melakukan pertukaran data elektronik tidak lagi secara manual. Dengan demikian dapat menekan biaya operasional pengurusan $D O$. Seharusnya semua proses penukaran delivery order, persyaratannya dan bukti transfer biaya pengambilan delivery order dikirim melalui email perusahaan ekspedisi muatan kapal laut (EMKL). supaya pekerjaan semakin mudah, praktis dan mengefisiensi waktu dalam mengerjakan pekerjaan lainnya. delivery order dan permohonan interchange bisa di stempel lalu discan dan dapat di email ke perusahaan EMKL.

b. Seharusnya bila terdapat peraturan baru yang dimunculkan oleh pihak pelayaran, pihak pelayaran harus mensosialisasikan ke semua pihak EMKL 
(Ekspedisi Muatan Kapal Laut). Persyaratan kelengkapan dokumen sangatlah penting dalam melengkapi pengeluaran delivery order dan apa saja yang dibawa dalam penukaran delivery order. Bea Cukai saja membuka sosialisasi melalui pesan whatsapp dalam pelayanan ke pihak EMKL (Ekspedisi Muatan Kapal Laut). Jadi bila perusahaan EMKL atau Importir bertanya-tanya bisa langsung berkomunikasi tanpa langsung datang ke Bea Cukai guna mensosialisasikan pelayanan pelanggan.

\section{SIMPULAN}

Proses penanganan impor barang menggunakan bill of lading original yang ditukar dengan delivery order online di perusahaan pelayaran dan di job orderkan (dicetak) menggunakan aplikasi Clique-247 menjadi elektronik container equipment interchange receipt untuk petikemas keluar dari pelabuhan sandar guna mempercepat penanganan impor barang bagi pengguna jasa dan pemberi pelayanan jasa untuk bekerja dengan praktis. Sistem online booking dalam aplikasi Clique-247 dan dikolaborasi dengan penukaran delivery order secara online membuat kerja operasional semakin mudah dan praktis. Dalam hasil penelitian di lapangan, dapat disimpulkan sebagai berikut :

a. Proses penukaran delivery order bisa dilakukan saat kapal sudah sandar di pelabuhan. Penukaran delivery order memiliki persyaratan membawa Bill of Lading $(B / L)$ original, Surat Tugas Pengambilan delivery order dari perusahaan, foto copy identitas diri, Permohonan Interchange, Surat Persetujuan Pinjam Container dan bisa digantikan dengan Letter Of Indemnity (LOI). Biaya pembayaran pengambilan delivery order bisa dilakukan dengan membayarnya transfer melalui bank dan tunai di perusahan pelayaran. Apabila persyaratan sudah lengkap dan pembayaran sudah dilakukan di pelayaran, maka delivery order bisa dikeluarkan oleh pihak pelayaran.

b. Perusahan Ekspedisi Muatan Kapal Laut (EMKL) bisa menggunakan Aplikasi Clique-247 dengan syarat mempunyai User ID dan User Web Access Terminal Petikemas Surabaya untuk bisa mencetak elektronik container equipment interchange receipt di pelabuhan Terminal Petikemas Surabaya. Selain itu dalam mencetak (e-CEIR) elektronik - container equipment interchange receipt, dokumen yang dibutuhkan adalah surat persetujuan pengeluaran barang dan delivery order. elektronik - container equipment interchange receipt (e-CEIR) dicetak 3 rangkap untuk diberikan kepada Terminal Petikemas, Depo Petikemas dan Pelayaran.

\section{DAFTAR PUSTAKA}

Berata, I komang oko, (2014). Panduan Praktis Ekspor Impor. Jakarta : raih asa sukses

Nugahani Farida, (2014). Metode Penelitian Kualitatif dalam Penelitian Pendidikan Bahasa. Cakra Books.

Semiawan Cony R, (2010). Metode Penelitian Kualitatif Jenis, Karakteristik dan Keunggulannya, Jakarta : PT. Gramedia Widiasarana Indonesia 
Saut Gurning,Raja Oloan, (2007).Manajemen Bisnis Pelabuhan. Surabaya: PT.Andhika Prasetya Ekawahana

Salim dan Syahrum, (2012). Metodologi Penelitian Kualitatif. Bandung : Citapustaka media

Soedjono, (2016). Kepabeanan, Imigrasi dan Karantina:Surabaya : Buku Stia dan Manajemen Barunawati

Soedjono, (2017). Freight Forwading. Surabaya: PMN

Yahya, M Iqbal, (2012). Export-Import. Jakarta:Lentera Ilmu Cendekia

Peraturan Menteri, (2017). Pelayanan Pengiriman Pesanan Secara Elektronik (Delivery Order Online) Untuk Barang Impor Di Pelabuhan 2017. Kementerian Perhubungan Republik Indonesia

Direktorat Jendral Perhubungan Laut dam Kementrian Perhubungan, (2017). “ Kemenhub Luncukan Aplikasi Inapornet 2.0 dan DO Online di Lima Pelabuhan. Hubla.dephub.go.id

Undang-Undang Republik Indonesia, (2008). Informasi dan Transaksi Elektronik 2005-2008. Presiden Republik Indonesia.

http://portal.inapornet.com/abouthtml

http://www.Solusimas.com/halamans/edo

http://www.tps.co.id/id-id/berita/press-release/listing/2017/09/06/09/23/hari-

pelanggan-nasional/ 